\title{
Discourses of Race \& Racism Within Environmental Justice Studies: An Eco-racial Intervention
}

\author{
By Perlita R. Dicochea, Santa Clara University
}

\begin{abstract}
The social force of racism in relation to natural resources plays a prominent role in the development of environmental justice (EJ) studies within the United States. I contend that the dominant paradigm of environmental racism (ER) may encourage superficial applications of race and racism and colorblind approaches to EJ. I argue that race and racism are at times essentialized, which has in part to do with essentialized notions of the environment. The goal of this eco-racial intervention is to encourage more explicit engagement with the dynamic ways that society creates meaning around and makes use of race and natural resources in relation to each other, processes that may include and operate beyond conventional and critical approaches to ER. Spirited by critical ER and racial formation theory, I propose the construct 'eco-racial justice project' as part of an alternative framework for evaluating racialization within efforts to achieve environmental justice.
\end{abstract}

\section{Introduction}

The social force of race in relation to natural resources plays a prominent role in the development of environmental justice studies within the United States. Many have recorded the history of data gathering that founded environmental racism as an analytic framework (Bullard 1993a, 1993b; Pulido 1996a, 1996b; Bullard 1997; Agyeman, Bullard, et al 2003; Visgilio and Whitelaw 2003; Pellow and Brulle 2005; Manaster 2005). Studies by environmental justice (EJ) scholars demonstrate that racism is related to multiple social discourses and structures, and is imbedded in dominant value systems (Hurley 1995; Pulido 1996a; Bullard 1997; Laduke 1999; Cole and Foster 2001; Gedicks 2001; Peña 2005; Lipsitz 2012). While EJ studies has grown since initial assertions of environmental racism (ER) in the 1970s, and a few EJ scholars offer alternative, critical approaches, I contend that as a theoretical paradigm ER remains under-analyzed in some social science EJ scholarship. Building on the work of Michael Omi and Howard Winant (1994), I argue that in the dominant ER discourse relations between race and natural resources are often only observable as specific types of racist eco-racial projects. I intercede an eco-racial consciousness in order to foster more analytic scrutiny of ER metanarratives and expand the vision for assessing relationships between racial and environmental processes.

This eco-racial intervention is intended to encourage more direct engagement within the field of EJ with the dynamic ways in which society creates meanings around and makes uses of race and environmental resources in relation to each other by building stronger connections to racial formation theory. Some EJ scholars hold conflicting views in debates about ER, and present different directions for further analyses of race, racial projects, and White privilege in relation to environmental inequalities (Pulido 1996b, 2000; Bolin G., Grineski S. E., and Collins, T. 2005; Lipsitz 2012). My focus regards the restrictive understandings of environmental racism that are maintained and unquestioned in prominent EJ texts, are detached from critical evaluations of ER, and at times erect debilitating boundaries around the presence and contours of race in relation to natural resources. The theoretical implications include the promotion of essentialist applications of race, racism, the environment, and a colorblind or homogenizing tendency in the use of the phrase 'environmental justice'. I promulgate that racial formation theory facilitates an alternative notion of the environment - one that includes where we live, work and play - as many EJ scholars and activists assert; nature, as mainstream environmentalists understand it; as well as the processes by which we create meanings that impact and are impacted by, among other things, racial, gender, and class formations.

In this essay, environment indicates relationships between various social and environmental forces. 
Natural or environmental resources refer to elements and systems of the natural world, as forces of their own, upon which communities place diverse values. Environmental processes include the role that humans play in negotiating and shaping natural resource developments. Resources broadly represent any type of natural or social resource.

In the following I address a) dominant social scientific paradigms of ER developed within environmental justice studies, b) one theoretical and one applied example wherein rigid approaches to environmental racism feature significant epistemological limitations about both race and racism, and c) my own struggle to apply ER concepts to a transnational water pollution problem in Baja and Southern California. I conclude this intervention with a synopsis of an eco-racial awareness that builds on critical ER thought and racial formation theory.

\section{Dominant Paradigms of Environmental Racism in the US}

Environmental racism as a specific movement and concept evolved from community-based leadership and research around unequal environmental policy enforcement that heightened public awareness of the relationship between the placement of toxic waste sites and communities of color in the United States. The United Church of Christ Commission for Racial Justice 1987 report, Toxic Wastes and Race in the United States, as well the U.S. General Accounting Office 1983 report, Siting of Hazardous Waste Landfills and Their Correlation with Racial and Economic Status of Surrounding Communities, employed the concept environmental racism (ER) and concluded that low-income communities of color are disproportionately impacted by the negative social, economic and public health effects of hazardous waste facilities and uneven environmental regulation enforcement (Agyeman, Bullard, Evans 2003; Visgilio and Whitelaw 2003; Bolin, Grineski and Collins 2005; Pellow and Brulle 2005; Manaster 2005). In the tradition of these initial reports, Bunyan Bryant (2002) defines environmental racism as:

.....those institutional rules, regulations, and policies or government or corporate decisions that deliberately target certain communities for least desirable land uses, resulting in the disproportionate exposure of toxic and hazardous waste on communities based upon certain prescribed biological characteristics. (p. 4)

Bryant's definition draws significantly from earlier ruminations grounded in community-based experiences and knowledge. For example, Benjamin Chavis, Jr. (1993), a reverend who participated in the United Church of Christ Commission for Racial Justice that produced the aforementioned 1987 report, includes racial discrimination as a factor in environmental policymaking, the enforcement of regulations and laws, the deliberate targeting of communities of color for toxic waste disposal, and the deliberate targeting of communities of color for the siting of polluting industries in his formulation. Chavis adds further that ER is evident 'in the official sanctioning of the life-threatening presence of poisons and pollutants in communities of color' (p. 3), and in the exclusivity of predominantly White, mainstream environmental groups, decision-making boards, commissions, and regulatory agencies. Bryant's 2002 definition likewise includes 'the unequal protection against toxic and hazardous waste exposure and the systematic exclusion of people of color from environmental decisions affecting their communities' (p. 4).

Peter Riech (2005) notes that some policy structures at the state level have developed understandings of equal protection, environmental decision-making procedures, and related socioeconomic impacts, providing a foundation for implementing race in environmental policy. Arguing similarly for an approach to race beyond juridical constructs, Luke Cole and Sheila Foster (2001) outline three pillars for framing environmental racism that:

.....1) retains a structural view of economic and social forces as they influence discriminatory outcomes, 2) isolates the dynamics within environmental decision-making processes that further contribute to such outcomes, and 3) normatively evaluates social forces and environmental decision- 
making processes which contribute to disparities in environmental hazard distribution. (p. 65)

While moving beyond strictly legal understandings of environmental racism, Riech, Cole and Foster maintain a preoccupation with state-sanctioned processes that differentially distribute environmental burdens.

Efforts to expand the boundaries of environmental racism as a concept by focusing on those who benefit from environmental inequalities and socio-spatial relations have not been thoroughly integrated within EJ studies. For instance, aspects of Robert Bullard's (1993) theorizing appear rather conventional as he promulgates that ER:

......refers to any policy, practice or directive that differentially affects or disadvantages (whether intended or unintended), individuals, groups, or communities based on race or color. It also includes exclusionary and restrictive practices that limit participation by people of color in decision making boards, commissions, and regulatory bodies. (p. 23)

However, Bullard also recognizes that the burdens imposed primarily on communities of color are relationally beneficial to Whites and reflect racialized power imbalances. Similarly, George Lipsitz (2006; 2012), Bob Bolin, Sara Grineski, and Timothy Collins (2005), and Laura Pulido (2000) contend that White privilege, as a direct result of, in Lipsitz's terms, the possessive investment in whiteness, reinforces historical and on-going, hegemonic socio-spatial patterns of environmental racism. In addition, Pulido (1996b) delineates the shortcomings of reductive positivist rationality underpinning some critiques of ER that relegate racism to overt acts, do not see racism as ideology in addition to institutionalized practices with structural impacts, and only understand racism in a fixed, singular form. In another analysis, Pulido (2000) argues that ER is facilitated by land use, residential patterns, and industrial development. In both essays (1996b; 2000), Pulido emphasizes racist racial projects, a tool within racial formation theory. Focused on racialized landscapes, Pulido asks readers to consider 'what race means to people and how racism shapes lives and places' (p. 33). These alternative, or critical, ER voices present new directions that EJ studies has yet to fully exploit.

In summary, whether focusing on the disadvantaged or the privileged, the dominant discourse of environmental racism underscores structures and institutions as mechanisms that facilitate unequal outcomes in the distribution of resources or enforcement of environmental policy along White/nonWhite racial lines. In more conventional understandings, ER is located in situations where communities of color experience the disproportionate impact of, or unequal protection from, environmental problems - two key pillars of EJ policy (Manaster 2005). In order for a group to be disproportionately impacted by an environmental ill, this group must be concentrated or isolated in some way either by experiencing a level of segregation and/or another form of discrimination - such as hiring practices that target a specific group - thereby emphasizing the importance of a network of social structures in creating and maintaining racial inequality. These paradigms focus on racism as a structural process happening to communities of color that lack the resources or social position to partake in decisions that shape their communities. Furthermore, Bryant's (2002) idea of ER as 'an extension' implies that racism only becomes systematic or uniquely complicated when encountering environmental problems. This perspective is disengaged from the critical ER advances discussed above, conflicts with racial formation theory, which I elaborate on below, and narrows the scope for observing and assessing race and racism in relation to natural resource values and uses.

Bound by the machinations of established institutions and a specific view of environmental resources as either burdens or benefits, conventional ER frameworks continue to privilege state-sanctioned discourses, processes, values, and procedures in identifying and ameliorating environmental racism. Understanding ER as an occurrence that is furthered or violated within state-sanctioned mechanisms 
marginalizes those discriminatory acts and discourses that occur beyond the confines of dominant institutions. As a result, opportunities to evaluate and theorize coexisting and conflicting functions of race and racism as manifested through both official and non-official discourses and practices which may resist, reinforce or otherwise impact environmental inequalities are overlooked.

I assert that the compartmentalized and, at times, over-determined location of race in some EJ research is indicative of dominant and uncontested notions of environmental racism developed within the field. While more critical ER thought is present within EJ studies, simplified applications of race and racism may be encouraged, and theoretical development of the relations between race and natural resources are stifled. Moreover, some EJ scholars confine race to specific forms of racism thereby collapsing conceptions of race with racism and under-analyzing the workings of both social forces. As cases in point, below I review a theoretical article by Gary C. Bryner (2002) and an applied article by Beverly Wright (2003), neither of whose essays have been assessed for their employment of race and racism.

\section{Applications of Environmental Racism: A Theoretical Example}

Gary C. Bryner's (2002) conceptual piece categorizes various methods for approaching environmental justice. He defines environmental injustice as a problem regarding the uneven societal distribution of environmental burdens and benefits. He identifies five frameworks: Civil Rights; distributive justice and ethics; public participation; social justice; and ecological sustainability. Bryner locates race under the Civil Rights and Social Justice frameworks. In both frameworks, the significance of race is attached to legal discourse and only relevant within forms of racial discrimination.

In his overview of the Civil Rights framework for pursuing environmental justice, Bryner addresses statutory law and constitutional provisions to mitigate disparate environmental impacts as they reflect racial inequities. Under this framework, Bryner maintains, EJ activists and scholars are most concerned with 'the extent to which communities of color are seen as sacrifice zones for pollution and hazardous waste' (p. 35). Bryner pinpoints some weaknesses of the Civil Rights approach including, for constitutional claims, the difficulty of proving intent to discriminate, and, for both statutory and constitutional claims, and the exclusion of class as an outcome of environmental disparities. Furthermore, Bryner discusses the tension between the competing principles of non-discrimination and racial preference. Non-discrimination prohibits consideration of race in decisions that impact the natural environment as a method to halt further racial disparities. To this approach, Bryner asks, what of current environmental resource disparities resulting from historical racial inequalities? A focus on race, or 'preferential treatment' (p. 38), and compensatory measures are noted as alternative approaches within the Civil Rights framework that Bryner states would address 'past discrimination' (p.38).

In response to the aforementioned tensions, Bryner calls for a new perspective on rights:

......not just as restraints on government, but as ways of empowering individuals, reinforcing our responsibility for one another and for the kind of society that we are part of, and asserting the moral and social responsibilities we have in common. (p. 39)

He adds:

......rights can help foster common concerns and encourage us to commit to ensuring that each person enjoys access to natural resources and environmental quality, which are essential for realizing a meaningful life and enjoying real equality of opportunity. (p. 39)

In focusing on the individual, Bryner's reply to the gaps in the Civil Rights approach to achieve environmental justice is as race-blind as it is dismissive of societal patterns that continue to privilege 
Whites, as a group, and disadvantage many communities of color. Here, the relational aspects of group differences reflective of power imbalances offered by Bullard, Lipsitz and Pulido may have corrected for Bryner's individualistic approach to resolving racial disparities.

Interestingly, Bryner mentions that the distributive justice framework furthers the preferential racial treatment approach by ensuring that 'the risks of environmental harms and the benefits of natural resources are spread more evenly' (p. 38). However, race and racism do not make explicit appearances in Bryner's overview of distributive justice and, thus, are not theorized. Within the Civil Rights section, Bryner acknowledges preferential treatment as a way to compensate for 'past discrimination' (p. 38). This interpretation of racial inequality as a past event evades legal discussions that explain distributive justice and concurrent policies such as affirmative action (which Bryner refers to as preferential treatment) as methods for disrupting contemporary social systems that reinforce White privilege in the present moment (Harris 1993). Bryner also misconstrues the role of history - acknowledging past discrimination is not the same as acknowledging the historical legacies of contemporary racism and contemporary White privilege.

The social justice framework reviewed by Bryner might provide a pathway to explore various other sites for theorizing race in relation to EJ frameworks, however, here too, Bryner situates the discussion of race strictly within the discourse of critical race theory and he lessens the significance of race by emphasizing class. According to Bryner's understanding, the social justice approach considers various inter-related social problems, the roots of which are uneven distributions of political power. He contends that this approach 'reaches much deeper than race to address fundamental issues of class' (p. 47). On the subject of the relationship between race and class, whiteness studies showcases examples of environmental racism wherein race prevails over class as the primary discriminatory rationale, or functions inextricably with class to reinforce social and economic disparities. For instance, Lipsitz demonstrates how federal policies such as the GI Bill, interstate highway construction, and governmental and private home lending entities facilitate concentrations of Whites and wealth. Along these lines, David Roediger (2005) argues that federal policies helped many blue-collar off-Whites, Eastern and Southern Europeans who came to the US in the late nineteenth century, move into the White middle class in the early twentieth century by expanding employment opportunities and increasing access to social and economic benefits. Thus, to maintain that the social justice approach to EJ is characterized by the 'deeper' critique of class disparities skews the social justice perspective and assumes that a class analysis is in fact more complex than, and disassociated from, that of race in all cases at all times. Consequently, Bryner implies that racism exists as a superficial feature of society that is merely symptomatic of, yet unrelated to, something else.

While Bryner recognizes that a faction within the social justice approach focuses on race, here he narrowly fixates on a critique of legal discourse via critical race theory. He writes:

Critical race theory is based on the experience, traditions, culture, and perspective of people of color. It offers a race-conscious perspective by which legal doctrines and decisions are critiqued. Rather than color blindness, critical race theory calls for race consciousness - analysis that is rooted in the history of American race relations, that recognizes major economic differences between White and black communities, and that seeks to develop a distinctive set of legal theories and principles rooted in those differences. (p. 48)

Bryner elaborates that critical race theory also identifies the need for more 'minority scholars' to partake in developing civil rights law, yet, he does not identify race relations and economic differences beyond a Black/White binary. Furthermore, Bryner leaves uncontested the idea that the essentialized experiences of 'the minority' may facilitate the development and implementation of more just natural resource law and policy. 
Under Bryner's assessment, I maintain, race and racism do not exist without the presence of the legitimating juridical process and legal discourse. Effectively, Bryner contributes to the limits of claiming environmental racism by acknowledging race only as racism and then placing racism within the confines of the Civil Rights Act and critical race theory. Bryner's restricted vision is not coincidental-the genealogy of race-thinking within EJ studies remains rooted in very particular designs of environmental racism. Indeed, the anthology in which Bryner's piece is published, Justice and Natural Resources (Mutz, Bryner et al 2002), maintains boundaries around racism. While striving to expand 'traditional' (p. 3) EJ studies by calling for the broad inclusion of natural resource management issues, the introductory chapter issues Bryant's assertion that ER is "an extension of racism" (reviewed above). In effect, the anthology as a whole does not directly grapple with the applied or theoretical deficiencies of traditional ER paradigms.

\section{An Applied Example}

In an applied analysis of the Mississippi River chemical corridor, Beverly Wright (2003) focuses on the impacts of pollution and environmental racism on the residents of Norco, located within 'Cancer Alley' (p. 125). As noted in the introduction and the first half of the article, Wright's application of environmental racism is US-based, which she describes as:

.....spawned from a history of human slavery and is a by-product of racial segregation and discrimination legitimated in the southern US with the enactment of Jim Crow laws that made all form of segregation and discrimination legal. (p. 125)

This interpretation of ER is specifically centered on the Black experience of slavery in the US and discriminatory policies that enforced racial segregation and inequality in the South. Wright notes that other parts of the US implemented similar discriminatory practices even in the absence of Jim Crow laws. She contends, 'Environmental racism is merely one of the vestiges of the overall pattern and practices of racism and discrimination in the US' (p. 125). Surely, the history of slavery, Jim Crow, and other policies, like anti-miscegenation laws and residential covenants, are important events that contextualize racial patterns and racial inequities. However, the foundations for racism cannot be reduced to the Black experience of racism in the U.S. It would logically follow that an ostensibly general framework of ER should not be reduced to the specific experiences of environmental injustices within Black communities.

Wright offers a particular genealogy of ER as though it were a universal one when in fact her definition is geared only toward contextualizing the experiences of a specific predominantly Black community in Louisiana. It would have been more appropriate for Wright to offer a list of examples such as those offered by Chavis and Bryant and analyze, as one example, the struggles of the black community of Norco which has experienced negative health and environmental impacts from the activities of the Shell Chemical Corporation. In fact, Wright's review of the development of Louisiana's oil economy delineates the coordination between the oil industry and state and local government, in facilitating the oil economy's dominance, and offers much to the discussion of the network of processes and social contracts within and between dominant institutions that often exacerbate patterns of racially differential public health impacts. Hence, Wright offers a complex historical, social, economic, and political overview for understanding the positionality of the community of Norco in relation to the local oil economy, one that reaches far beyond the operating definition she offers of ER.

Most problematic is the leap Wright makes from assessing racial dynamics and the polluting oil industry in Louisiana to an evaluation of the impact of Nigeria's oil economy on the Ogoni tribe, the latter of which is not mentioned in her introduction. Mid-way through the article, Wright employs a new framework for the comparative analysis that involves six factors identified by a non-profit group, the International Possibilities Unlimited. These factors are oil, minority group status, poverty, 
multinational corporations, human rights' violation, and environmental devastation. The experience of the Ogoni tribe in Ogoniland, Nigeria, and residents of Norco share in common the development and impacts of the oil economy and communities in both regions might have predominantly black skin color, however, Wright does not offer a reasonable explanation for employing one specific definition of environmental racism for these two divergent communities. The lack of elaboration on the efficacy of defining and applying race and racism in an article that includes a black community in Louisiana and a tribal group in Nigeria provides readers with a superficial understanding of both race and racism.

Wright mishandles the experiences of two Black communities with two distinct histories and social circumstances in relation to race and oil in two completely different parts of the world. As a result, Wright reinforces binary notions of race and racism as a Black/White dynamic. While she concludes that 'race, politics, and pollution all combine to place minorities and the poor at greater risk from exposure to toxic chemicals around the world' (p. 143), the complexities of race and racism in the context of Nigeria's power relations are left unexplored. The result is that Wright imposes a specific kind of US - based race-thinking on a tribe in an African country, misconstrues processes of racialization, and circumvents an opportunity to add to comparative, transnational studies of ER.

Wright's analysis is published in the anthology Just Sustainabilities: Development in an Unequal World (Agyeman, Bullard, et al 2003). The relationship between environmental quality and human equality is the overarching theme through which the anthology aspires to facilitate the achievement of social and economic equity between, and within, nations. Race is represented by examples of environmental racism - namely, the disproportionate impact of environmental harms on non-White communities - and presented as a symptom of economic or other social patterns related to income inequality, political rights, civil liberties, economic opportunity, or literacy. The lurking presupposition is that if we address those other indicators of inequality, somehow environmental racism (and perhaps race itself) will disappear. By not applying analytic rigor to the social forces of race and racism as they shape and are shaped by environmental processes in the transnational scene, much of what we think we know about race and environmental racism remains unscrutinized. Consequently, for Wright's units of analysis the anthology offers a lack of guidance for unpacking what it means to be Black and experience environmental racism in one region of the US versus Nigeria.

\section{Environmental Racism on the Borderlands}

Similar to the problems I identify in the work of Wright and Bryner, metanarratives of ER do not capture the intricacies of cultural identity, class, cross-border social positions, race, and racism that I encounter in my analyses of the bi-national New River pollution problem that flows south from Mexicali, Baja California through a predominantly Mexican and Mexican American population in the City of Calexico, located in Imperial County, California (Dicochea 2006; 2010; 2012). The River is composed of a toxic mix of agricultural, industrial and household run-off including a long list of chemicals and biological contaminants that threaten the environment and public health. How does one pinpoint environmental hazard exposure when both the polluted environmental resource and the surrounding communities are mobile? While there is a growing body of literature addressing border region environmental problems through an environmental justice lens (Peterson, Peterson and Peterson 2007; Sandler and Pezzullo 2007; Grineski and Collins 2008; Johnson and Niemeyer 2008), there continues to be a lack of explicit confrontation with concepts of race and environmental racism on the borderlands. Instead racialization often looms within EJ research conducted in Othered border regions, which tends to homogenize borderland communities and thwarts our comprehension of how such 'Othering' occurs in the context of both US and Mexican racial sensibilities. Where is race and environmental racism located and how are these social forces observed in a transnational community of predominantly Mexicans and Mexican Americans? 
In one aspect of my research, I employ ER as a framework in tandem with a distributive justice argument by shifting the geographic and political scope of my analysis (Dicochea 2006). When focusing on the problem of New River pollution in the U.S., I make the case for environmental racism given the significantly uneven distribution of resources from state and federal agencies - including financial assistance, research commitments and expert attention - by the border communities of Imperial County versus San Diego County for similar transnational water pollution problems. San Diego County has received an unprecedented amount of financial assistance from the California Environmental Protection Agency (Cal/EPA), which will likely not be offered to any other border region in the future (Dicochea 2006; 2010). Demographic and other variables distinguish the two counties, - with Imperial County characterized by a much higher percentage of Spanish-dominant households, consistently higher rates of unemployment, and a higher percentage of persons living at, or below ,the poverty level in comparison to San Diego County and the rest of the state (Dicochea 2006; 2010; 2012). The border community of Calexico (population 30,000) is particularly vulnerable as the first US recipient of the toxic River.

When shifting the scope of my analysis to compare and contrast Mexicali (population 1 million) with Calexico, I contend that over-determined ideas about what ER looks like may mask the multifaceted social and environmental inequalities that manifest within racial groups on the borderlands. The concept of environmental racism does not reflect the various hierarchies within the Mexican and Mexican American communities on both sides of the border that may be at once benefiting from, and burdened by, the New River catastrophe. While the downstream community of west Calexico faces more direct exposure because the river flows through an older neighborhood, some upstream neighborhoods in Mexicali situated directly on the riverbanks appear to be just as and, in some cases, more exposed. Observing these complications, I struggle to apply ER as a framing mechanism when analyzing the cultural, economic, and environmental impacts of transnational water pollution, not because race and racism vanish at the border, but because existing definitions of ER do not capture what I observe.

In other developments of my research, I employ borderlands thought in partnership with bioregionalism and assert that it is necessary to apply a layered observation to the region's New River contamination problem - one that considers material and ideological political divides that coexist with material and ideological cross-border ways of living and knowing (Dicochea 2010). Borderlands thought acknowledges the ways that people draw from multiple cultural values and in the process negotiate various forces of power. Bioregionalism encourages communities to organize around the natural contours of environmental resources including regional weather patterns, flora and fauna, and watersheds. Because a bioregional way of life that is undeterred by political boundaries does not reflect the present moment, I conclude that the communities surrounding the River are located somewhere between borderlands and bioregionalism in terms of both their lived and perceived realities.

I further grapple with the intricacies of intra-racial hierarchies and competing notions of environmental justice in my assessment of the Cal/EPA's Environmental Justice Pilot Project (EJPP) for the New River (Dicochea 2012), initiated by a chemist of the State Water Resources Control Board (SWRCB) who is of Mexican heritage. A local non-profit made up of predominantly Mexicans and Mexican Americans the Calexico New River Committee (CNRC) - represents for the SWRCB the key grassroots organization to partner with in order to ensure meaningful participation in the Pilot Project. Having conducted extensive fieldwork that includes in-depth interviews, contingent valuation surveys, ethnography, and participant observation, I conclude that the CNRC is reflective of a tight group of mostly male local elites. My data reveals diverse views and tensions within the community of Calexico as some residents support the CNRC while others distrust its plans and leadership (Dicochea 2010). SWRCB officials involved in the New River issue - the majority of whom are Latino - partner with the CNRC 
as the lead local group because of the non-profit's regional and state-wide political momentum garnered previous to the inception of the EJPP. I suggest that the Cal/EPA officials involved overlook hierarchies within a predominantly Mexican and Mexican American population, thereby embracing a class- and gender-blind notion of the grassroots. Furthermore, I argue that the CNRC's goals conflict with the SWRCB's methods for achieving justice, evident in the discourse of cumulative impacts -emphasized by the CNRC - and the precautionary approach - emphasized by the SWRCB. The concept of cumulative impacts allows the CNRC to further its objective to encase three miles of the River in order to increase economic development in the western region of Calexico. Meanwhile, the SWRCB employs the concept of the precautionary approach to critique the CNRC's plan to encase the River, which participating SWRCB officials characterize as a shortsighted, band-aid measure.

In summary, multiple meanings of race and justice collide and individuals representing various racialized groups appear on all levels of the social order, on all sides of a political boundary, and may atonce benefit from and be burdened by a given pollution problem in border regions. Some borderland dwellers may spend much of their lives on both sides of a national border and maneuver through various kinds of pollution and a web of cultural forces. In situations of daily or seasonal migrations, the idea of a community as a deliberate target is not very useful because it is nearly impossible to determine a single, deliberate perpetrator in cases where pollution and people are mobile. Conceptions of ER that focus narrowly on disproportionate impacts and unequal protection are also inadequate for capturing more nuanced workings of dominance and power within race relations, one that may involve convoluted engagements with accommodation, resistance, negotiation, and compromise.

I invite EJ scholars to explicitly test the strengths and weaknesses of ER as a framework lest we subvert the subject of co-existing axes of power and privilege and implement an ostensibly consistent perception of what it means to achieve environmental justice.

\section{Map of an Eco-racial Intervention}

Thus far, I espouse an eco-racial perspective in exploring the epistemological limits of the dominant paradigms of environmental racism within EJ studies. What proceeds is a synopsis of my main points of critique followed by an eco-racial reply that I craft in the spirit of both critical ER and racial formation theory.

1. ER is recognized as institutionalized racism and, to a lesser extent, institutionalized White privilege, thereby emphasizing structural forces. Eco-racial response: Processes of race and racism involve dynamic interplays between structural forces, or the social order, and ideologies, or discourse. White privilege and racism may shape and be shaped by cultural values revealed through physical or discursive acts and events, laws and policies, art and performance, social movements, government and non-governmental organizations at the individual, regional, national, or transnational level within and beyond state-sanctioned institutions. Race is a thoughtful and illogical, reasonable and irrational, rationalized and contradictory social contract-as is our relationship to the overall environment. I adjust Pulido's questions, presented earlier, and ask, What do race and environment mean to people and how do they interact to shape lives, places and natural resources? Thus, I assert that processes of race and racism must involve the interplay between structure, ideology, and environmental forces.

2. Conceptions of ER put forth as framing mechanisms are in actuality lists of examples of racism featured by the main problems of disproportionate impacts and unequal protection, and other related forms of discrimination and elitism versus over-arching theoretical blueprints. While reflecting important social inequalities, these lists indicate a tendency to essentialize race, racism, and the environment, meaning that these terms are perceived and operationalized in static or otherwise debilitating ways. Eco-racial response: Society places manifold and conflicting values 
on racialized human bodies and these values are relational to the variegated and competing values placed on environmental resources. Natural resources are value-laden, socially constructed, cultural and material forces that are ever-transforming. The diversity in the ways that the environment is defined and natural resources are utilized impacts communities differentially. Coexisting understandings of the environment in its many manifestations-as a burden, benefit, market, communal or spiritual value; as physical spaces where humans live or not; or as sites that engage various social forces-are community- and culturally-specific and imbued with relations of power.

3. U.S. racial sensibilities employed through an ER lens tend to homogenize non-White groups and oversimplify the genealogy of ER as experienced by non-White communities within and beyond the U.S. This pattern maintains the power of whiteness and other intersecting social privileges. Ecoracial response: The contexts of social and, I add, environmental resources are important to assess in observing difference and hierarchy within and between particular racial groups. The complexity of power relations is recognized in racial formation thought by the concept of hegemony, in which resistance, accommodation, coercion, consent, and negotiation may intermingle with patterns of environmental racism and struggles for environmental justice. I suggest we identify eco-racial projects and evaluate the extent to which they create, reinforce, resist, and/or transform racial and other social dynamics while influencing and being influenced by natural resource values and uses.

4. Environmental racism is at times characterized as merely symptomatic of presumably more significant or more powerful social forces, which explains colorblind approaches to environmental justice. Eco-racial response: This common theme contradicts over-determined notions of ER and fails to recognize EJ research that demonstrates situations wherein race plays the most important role in furthering unequal access to environmental amenities and disproportionate exposure to environmental harms. Alternatively, efforts to address racialized environmental disparities may be framed as eco-racial justice projects, which underscore the ways that race and racism are connected to environmental values and uses and encourage intentional engagement with the axioms of ER. Toward this end, we may ask, To what extent do environmental justice efforts impact racial segregation and racial discrimination, two major social patterns that are foundational to cases of disproportionate impact and unequal protection? What are the implications for racial formation theory when EJ efforts reinforce or transform structural inequalities or hierarchical discourse?

In racial formation thought, because every body is racialized in ways that reflect interests in, access to, and struggles over resources, race is not an ornament or externality, but an engrained aspect of the U.S. social fabric and environmental landscape. Subsequently, approaches to environmental justice must be contextualized within relational values and orders of race, racism, and natural resources. Addressing class inequities alone will not make race, racism, or environmental problems go away.

\section{Conclusion}

EJ scholars tend to be thinking too much alike in approaching race narrowly in terms of racist racial projects, in over-specifying the contours of environmental racism, or in evading analyses of racialization. Within EJ studies race is often held captive by racism, racism is contained within particular forms and functions, and efforts to include social systems of whiteness and its relationship to natural resource values remain ephemeral. An eco-racial consciousness may guide more captivating evaluations of race and racism as discursive and material forces allowing for the intentional consideration of the full spectrum of race-thinking and race-making as processes of power that are engaged by the more and less privileged within and beyond political borders and revealed in our complex, ever changing relationships with an equally dynamic and powerful natural world. 


\section{REFERENCES}

Agyeman, J., Bullard, R., and Evans, B. eds. (2003). Just Sustainabilities: Development in an Unequal World. London, UK: Earthscan Publications Limited.

Bolin B., Grineski S. E. and Collins, T. (2005). Geography of despair: Environmental racism and the making of South Phoenix, Arizona, USA. Human Ecology Review. 12(2), pp. 155-167.

Bryant, B. ed. (1995). Environmental Justice: Issues, Policies, and Solutions. Washington, D.C.: Island Press. Bryner, G. (2002). Assessing Claims of Environmental Justice: Conceptual Frameworks. In: Mutz, K., Bryner, G., and Kenney, D. eds. (2002), pp. 31-55.

Bullard, R. ed. (1993a). Confronting Environmental Racism: Voices from the Grassroots. Cambridge, MA: South End Press.

Bullard, R. D. (1993b). The Threat of Environmental Racism. Natural Resources and Environment. 7(3), pp. 23$26 \& 55-56$.

Bullard, R. D. (1997). Unequal Protection: Environmental Justice and Communities of Color. San Francisco, CA: Sierra Club Books.

California Environmental Protection Agency. (2010). Environmental Justice Program Homepage. [Online].

(Retrieved March 2011) (URL: http://www.calepa.ca.gov/EnvJustice/)

Chavis, B. F., Jr. (1993). Forward. In: Bullard, R. ed. (1993), pp. 3-5.

Cole, L. W. and Fpster, S. R. (2001). From the Ground Up: Environmental Racism and the Rise of the

Environmental Justice Movement. New York: New York University Press.

Dicochea, P. R. (2006). Environmental Injustices on the Mexico-United States Borderlands: The case of the New River. Ph.D. Dissertation, University of California, Berkeley.

Dicochea, P. (2010). Between Borderlands and Bioregionalism: Life-place Lessons along a Polluted River. Journal of Borderland Studies. 25(1), pp. 19-36.

Dicochea, P. (2012). Collaboration and Compromise at the Borderlands: The Cal/EPA's Pilot Project for the New River. Environmental Justice. 5(1), pp. 21-25.

Gedicks, A. (2001). Resource Rebels: Native Challenges to Mining and Oil Corporations. Cambridge, MA: South End Press.

Getches, D. H. and Pellow, D. N. (2002). Beyond "traditional" environmental justice. In: Mutz, K., Bryner, G., and Kenney D. eds. (2002), pp. 3-30.

Grineski S. E. and Collins, T. (2008). Exploring patterns of environmental injustice in the Global South:

Maquiladoras in Ciudad Juarez, Mexico. Population and Environment. 29(6), pp. 247-270.

Harris C. I. (1993). Whiteness as Property. Harvard Law Review. 106(8), pp. 1707-1791.

Hurley, A. (1995). Environmental Inequalities: Class, Race, and Industrial Pollution in Gary, Indiana, 1945-1980.

Chapel Hill, NC: University of North Carolina Press.

Johnson M. A. and Niemeyer E. D. (2008). Environmental Justice in the US-Mexico Borderlands. Human

Ecology. 36(3), pp. 371-382.

Laduke, W. (1999). All Our Relations: Native Struggles for Land and Life. Cambridge, MA: South End Press. Lipsitz, G. (2006). The Possessive Investment in Whiteness: How White People Profit from Identity Politics. Philadelphia, PA: Temple University Press.

Lipsitz, G. (2012). The Possessive Investment in Whiteness. In: Rothenberg, P. S. ed. (2012), pp. 71-94. Manaster, K. A. (2005). Environmental Protection and Justice. 2nd ed. Newark, NJ: LexisNexis Press.

Mutz, K., Bryner, G., and Kenney, D. eds. (2002). Justice and Natural Resources: Concepts, Strategies, and Applications. Washington, D.C.: Island Press.

Omi, M. and Winant, H. (1994). Racial Formation in the United States: From the 1960s to the 1990s. New York: Routledge Press.

Pellow, D. N. and Brulle, R. J. eds. (2005). Power, Justice, and the Environment: Toward Critical Environmental Justice Studies. In: Pellow, D. N. and Brulle, R. J. eds. (2005), pp. 1-19.

Pellow, D. N. and Brulle, R. J. eds. (2005). Power, Justice \& the Environment: A Critical Appraisal of the Environmental Justice Movement. Cambridge, MA: MIT Press.

Peña, D. (2005). Mexican Americans and the Environment: Tierra y vida. Tucson, AZ: University of Arizona Press.

Peterson M. N., Peterson M. J, and Peterson T. R. (2007). Moving toward sustainability: Integrating Social Practice and Material Process. In: Sandler R. and Pezzullo P. C. eds (2007), pp. 189-220.

Prindeville, D. M. (2003), For the People: American Indian and Hispanic Women in New Mexico's

Environmental Justice Movement. In: Visgilio, G. R. and Whitelaw, D. M. eds. (2003), pp. 139-57.

Pulido, L. (1996a). Environmentalism and Economic Justice: Two Chicano Struggles in the Southwest. Tucson, 
AZ: University of Arizona Press.

Pulido, L. (1996b). A Critical Review of the Methodology of Environmental Racism Research. Antipode. 28(2), pp. 142-159.

Pulido, L. (2000). Rethinking Environmental Racism: White Privilege and Urban Development in Southern

California. Annals of the Association of American Geographers. 90(1), pp. 12-40.

Reich, P. L. (2005). Greening the Ghetto: A Theory of Environmental Race Discrimination. In: Manaster, K. ed. (2005), pp. 224-25.

Roediger, D. R. (2005). Working Toward Whiteness: How America's Immigrants Became White. Cambridge, MA: Perseus Books.

Sandler R. and Pezzullo P. C. eds. (2007). Environmental Justice and Environmentalism: The Social Justice Challenge to the Environmental Movement. Massachusetts Institute of Technology: Cambridge, MA.

Rothenberg, P. S. (2012). White Privilege: Essential Readings on the Other Side of Racism. New York, NY: Worth Publishers.

Visgilio, G. R. and Whitelaw, D. M. eds. (2003). Our Backyard: A Quest for Environmental Justice. New York: Rowman \& Littlefield Publishers, Inc.

Wright, B. (2003). Race, Politics and Pollution: Environmental Justice in the Mississippi River Chemical Corridor. In: Agyeman, J., Bullard, R., and Evans, B. eds. (2003), pp. 125-145. 